\title{
Mediterranean Botany
}

ISSNe 2603-9109

\section{Landscapes and forest flora of al-Andalus: a reconstruction from textual historical documentation}

\author{
J. Esteban Hernández Bermejo ${ }^{1,4}$, Julia $\mathrm{M}^{\mathrm{a}}$ Carabaza Bravo², Expiración García Sánchez ${ }^{3}$ \& Francisca \\ Herrera Molina ${ }^{4}$
}

Received: 13 February 2017 / Accepted: 23 November 2018 /Published online: 20 February 2019

\begin{abstract}
The translation and interpretation of works by Andalusi botanists and agronomists provide an increasingly sharp image of the species and forest landscapes in al-Andalus (Iberian area under Muslim rule in the Middle Ages). Regarding agriculture, it is known that domestication processes and the introduction of new species and singular forms of use were carried out, thus changing agricultural landscapes. Consequently, new life styles and consumption habits developed. A lot less is known about forestry management, especially when referring to forest landscapes and tree species in the Iberian Peninsula.

The authors of this work have been studying agricultural and forest flora in al-Andalus for many years. In addition to numerous miscellaneous contributions, their first approximation on the trees and shrubs cultivated there was published in 2004, and the first volume of Flora Agrícola y Forestal de Al-Andalus covering 80 species of monocotyledons appeared in 2012. In anticipation of the volume devoted to woody dicotyledons to be published in 2019 (including over 150 species, 100 genera and 50 families), a synthesis of the forest landscapes and the most unique species in the Arabic texts is presented in this work. Among the taxa identified are Iberian endemics such as Flueggea tinctoria and Corema album, rare taxa or highly localized ones like Rhododendron ponticum subsp. baeticum, Tetraclinis articulata and Zizyphus lotus with species of peculiar forestry interest such as Arctostaphylos uva-ursi, Taxus baccata, Buxus sempervirens, Ilex aquifolium, Laurus nobilis and Vitex agnus-castus, and archaeophytes like Celtis australis or Anagyris foetida.
\end{abstract}

Keywords: Agronomy; domestication processes; forestry interesting species; trees; shrubs.

\section{Paisajes y flora forestal de al-Andalus: una reconstrucción a partir de documentación histórica textual}

Resumen. La traducción e interpretación de las obras de botánicos y geóponos andalusíes permite vislumbrar, de forma cada vez más nítida, las especies y paisajes forestales de al-Andalus (área ibérica bajo dominación musulmana en la Edad Media). En el ámbito agrícola es conocido que se desarrollaron procesos de domesticación e introducción de nuevas especies y formas singulares de uso que cambiaron los paisajes agrícolas y, en consecuencia, también las formas de vida y alimentación, pero es mucho menos conocido lo concerniente al ámbito forestal, especialmente si nos referimos a los paisajes y especies forestales ibéricas.

Los autores estudian la Flora Agrícola y Forestal en al-Andalus. Además de numerosas contribuciones misceláneas, una primera aproximación sobre los árboles y arbustos cultivados fue publicada en 2004, y un primer volumen de la citada Flora en 2012, abarcando 80 especies de monocotiledóneas. Como adelanto al volumen dedicado a las dicotiledóneas leñosas, que será publicado en 2019 (con más de 150 especies de 100 géneros y 50 familias), se presenta ahora una síntesis de los paisajes forestales y de las especies más singulares identificadas en los textos estudiados. Entre ellas hay endemismos ibéricos como Fluggea tinctoria y Corema album, taxones raros o muy localizados como Rhododendron ponticum subsp. baeticum, Tetraclinis articulata o Zizyphus lotus, junto a especies de singular interés forestal como Arctostaphilos uva-ursi, Taxus baccata, Buxus sempervirens, Ilex aquifolium, Laurus nobilis o Vitex agnus-castus, y arqueófitos como Celtis australis o Anagyris foetida.

Palabras clave: Agronomía; procesos de domesticación; especies con interés forestal; árboles; arbustos.

\section{Introduction}

A variety of information sources can be used in an ethnohistorical study: archaeological (bas-reliefs, ceramics); archaeobotanical (palynological records, seeds, coal, dendrochronology); biogeographical and climatological variations; floristic (traces of the past in today's landscapes and wildlife); artistic and graphic (engravings, drawings, photography) and textual (treaties on natural history, botany, pharmacology, medicine, agron-

\footnotetext{
Departamento de Ciencias y Recursos Agrícolas y Forestales, Universidad de Córdoba, Edificio Celestino Mutis. Campus de Rabanales. 14071 Córdoba. Spain. Email: cr1hebee@uco.es

Departamento de Estudios Semíticos, Universidad de Granada. Campus de Cartuja. 18071 Granada. Spain. Email: carabaza@ugr.es

Escuela de Estudios Árabes, CSIC. Cuesta del Chapiz, 22. 18010 Granada. Spain. Email: egarcia@eea.csic.es

Banco de Germoplasma Vegetal Andaluz. Junta de Andalucía. Avda. Linneo s/n. Córdoba. Spain. Email: cr2hemof@uco.es

1,3,4 Members of CultIVA - CYTED (www.cyted.org/es/cultiva).
} 
omy, travellers' descriptions, etc.) The exclusive use of any of these sources by itself often limits the results and, dispensing with the perspective and information of other approaches, entails the risk of making misinterpretations and low-level assessments of the data. The work presented in this paper has been done by a multidisciplinary team in which philological and historical backgrounds have joined up with agricultural, forestry and botany knowledge, resorting occasionally to anthropology, archaeology and pharmacobotany contributions. Part of the results already obtained in the general project for the identification and valuation of Andalusi species and agricultural and forest landscapes can be found in Carabaza (2004), Carabaza et al. (2001, 2004, 2014), García-Sánchez (1997, 2001), García-Sánchez et al. (1998, 2008), García-Sánchez \& Ramón-Laca (2001), García-Sánchez \& Hernández-Bermejo (2007), Hernández-Bermejo (1987, 1990, 1991, 1999), Hernández-Bermejo et al. (2012), and Hernández-Bermejo \& GarcíaSánchez (1998, 2008, 2009, 2015).

\section{Methodology and material}

\section{Arabic textual sources}

Landscapes have been reconstructed by means of the following texts:

- The Andalusi agronomists: Ibn Haŷŷây (XIth century), Ibn Wāfid (XI ${ }^{\text {th }}$ century), Ibn Bașșāl (XI ${ }^{\text {th }}$ century), Abū 1-Jayr (XI'th $-\mathrm{XII}^{\text {th }}$ centuries), al-Ṭignarī (XI ${ }^{\text {th }}-X I^{\text {th }}$ centuries), Ibn al-'Awwām $\left(\mathrm{XII}^{\text {th }}-\mathrm{XIII}{ }^{\text {th }}\right.$ centuries) and Ibn Luyūn $\left(\mathrm{XIV}^{\text {th }}\right.$ century).

- $\quad$ Agricultural calendars such as 'Arīb b. Sa'īd ( $X^{\text {th }}$ century) and Ibn 'A Așim's ( $\mathrm{X}^{\text {th }}-\mathrm{XI}^{\text {th }}$ centuries).

- The descriptions from travellers and geographers including al-Rāzī ( $\mathrm{X}^{\text {th }}$ century), al-Bakrī (XII ${ }^{\text {th }}$ century), al-Idrīsī (XII ${ }^{\text {th }}$ century), al-Himyarī $\left(\mathrm{XIII}^{\text {th }}-\mathrm{XIV}^{\text {th }}\right.$ centuries) and al-Maqqarī $\left(\mathrm{XVII}^{\text {th }}\right.$ century).
- $\quad$ Pharmacological treaties like those by Ibn Ŷulŷul ( $\mathrm{X}^{\text {th }}$ century), Ibn Wāfid ( $\mathrm{XI}^{\text {th }}$ century), Maimonides (XII ${ }^{\text {th }}$ century) and Ibn al-Baytậr (XIII ${ }^{\text {th }}$ century).

- There is a brilliant and notable botanical work attributed to Abū l-Jayr, entitled 'Umdat al- țabīb fì ma'rifat al- nabāt (the key book for a physician's knowledge of botany), that contains about 5000 records of plants, often accompanied by lengthy descriptions, references to uses and qualities, and interesting place names.

\section{Difficulties when studying textual sources}

Apart from the usual work of managing editions and translations of texts, other difficulties arising when identifying species were derived from the constant cases of polysemy, synonymy and local names given in medieval times (Hernández Bermejo, 1990). To establish a biunivocal correspondence between a scientific name and the taxon that a particular text is referring to becomes a complex work of research. This can only be solved by a diagnosis that, in many cases, does not have a minimal description of the morphological characters. These, hopefully, may appear in other botanical texts, as is the case of the 'Umdat al-țabīb but, more often than not, the diagnosis derives from the interpretation of uses, virtues, shapes, growing cycles, ecological requirements and locations where the plant was present. For this diagnosis work, it is very important for researchers to be able to consult the appropriate documentation and have as wide a knowledge as possible to enable them to set up the spatio-temporal probabilistic framework that allows confirmation of the presence of the taxon. It is necessary to handle the indigenous nature of plants, but also the process of their geographical dispersion throughout the history of mankind. (Figure 1).

For space reasons and consistency with the title, we shall not address the Andalusi agricultural landscapes, this work having been done elsewhere.

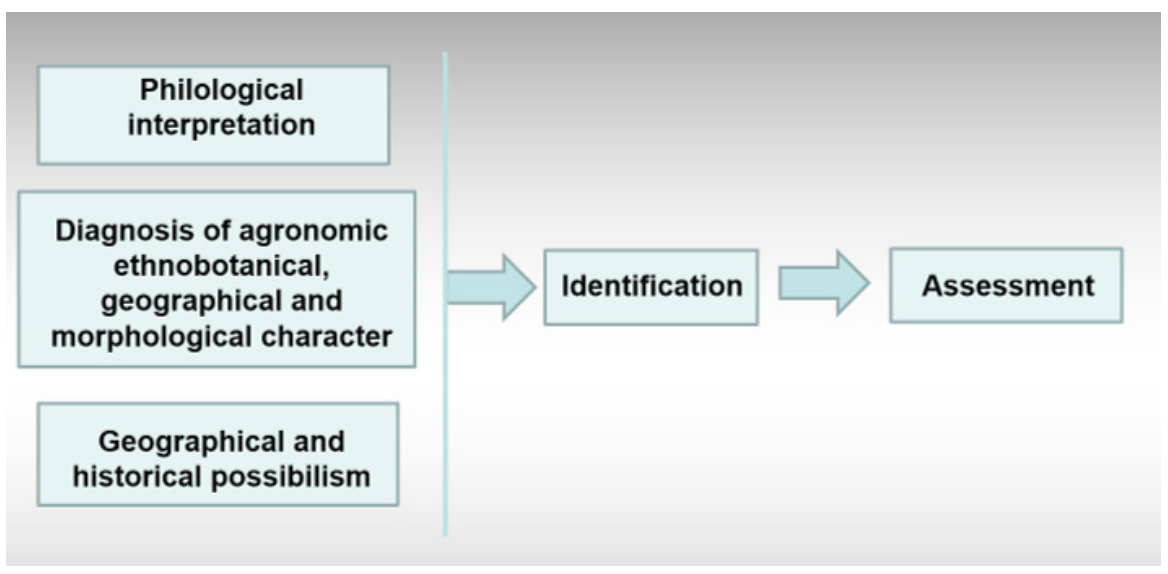

Figure1. Working methodology. 


\section{Forest landscapes}

\section{Mediterranean oak forests and dehesas (open oak forests)}

Abū 1-Jayr (2004-2010) describes the diversity of the Iberian Quercus taxa in Mediterranean environments grouped under the term ballüt; he distinguishes between long and short, sweet and sour acorns; Ballüt hulw (sweet oak) which could be identified with $Q$. ilex subsp. ballota $(=Q$. rotundifolia) in contrast with ballüt amāruh (sour oak, most likely the species type). Its wide ecological range is well explained by Ibn al- Awwām (1988): "the oak is a wild tree born per se in mountainous places, on hard and not hard grounds... and does not require much watering... it lives on many types of soils". The selection and planting of acorns give us indications of the domestication process carried out by the Iberian populations in order to obtain dehesa landscapes, covered by oaks with large, sweet acorns, far from the "montesinas" (mountain ones) variations, much smaller and bitter. Acorns were part of human consumption, employed even as flour for bread making. In addition, various medicinal virtues are mentioned (astringency, healing powers, treatment of ulcers, regulating menstruation), and their use as a tanning agent for treating leather and craftsmanship of the cordobans (high quality leather work). The quality of its wood was also appreciated, although nothing is said of its use as fuel.

Quercus coccifera, kermes oak, is clearly distinguished as being the species of Quercus producing quermes (small galls caused by insects from the group of Coccidae), from which the carmine used in cosmetics is extracted.

With regard to the cork oak (Quercus suber), we are told that its acorn is thick, black, short, veined, with a blunt tip and a bitter taste; it grows in the mountains and its leaves and wood resemble that of the oak tree.... it is the species on which cows and mules graze" (Abū 1-Jayr, 2004-2010) in reference to grazing pastures. Among the uses of this tree, cork for beehives is mentioned by Ibn al'Awwām (1988).

Regarding the Quercus faginea grex (Lusitanian oaks, "quejigos", gall oaks), we turn to Abū 1-Jayr (2004-2010) to find the "afs, which, he says, belongs to "the type of large trees, with leaves oak-like in shape and appearance, only wider and more whitish, very smooth". In the same text, there is a reference to "a larger-sized variety with bigger fruit, these being light, soft, and easily astringent and abounding in al-Andalus". We are probably being presented to the Baetic gall-oak, which could correspond to Q. canariensis or Quercus alpestris. The text includes information on the polymorphism of "quejigos" pointing out the existence of varieties with more festooned or crenulated leaves, recognized by different names.

\section{Thermomediterranean formations with palms, mastic and terebinth trees, myrtles and other thermophilous shrubs formations}

Regarding the thermomediterranean formations with myrtles and palmettos, we have highlighted Chamerops humilis (dawm) a species used as an alternative to esparto grass (Stipa tenacissima) and its historical and geographical locations in Cádiz, Jerez and Medina Sidonia. Myrtus communis (rayhān) is recognized as being a tree, with some authors making a persistent reference to its use as an ornamental plant, and its plantation in pools is suggested. A "very rich food and bread" was said to be made with its fruit, but no author mentions fresh consumption or the possibility of its being prepared in the form of jams or syrups. The cosmetic properties of leaves and seeds are also described: for hair treatments and deodorants, and antiseptics, healing, cleansing, antihistamine, phytosanitary products, etc. There is unanimity among the geoponists on the existence of wild varieties along with the cultivated one. A surprisingly hairy variety is mentioned by Abū l-Jayr and noted by Ibn al-'Awwām (Carabaza et al., 2004).

The presence of wild olive ("acebuche") in these thermomediterranean formations, and of carob trees, is well documented, given that all the Andalusi agronomists cited them. Referring to the carob tree (Ceratonia siliqua), Ibn al-'Awwām (1988) writes that it grew wild in the mountains and makes accurate statements about its edaphic requirements, varieties, uses as human and livestock food and medicinal virtues, especially its astringent character.

Related to these thermophilous formations, the date palm (Phoenix dactylifera) is mentioned as what could very well be the cosmic tree of Arabic culture, which illuminated the Andalusi period, from the east of the Mediterranean to the North of Africa (Sanz Elorza et al., 2010). The profound knowledge of its cultivation demands, ecology, propagation forms and reproduction system is evident from the wealth of observations made by all the authors studied. The palm is conceived as being a projection of man himself: its sexuality, affinities with other trees and diseases or stages of growth (al-Tignarī, 2006). From the standpoint of its usefulness, the palm provides not only dates as food, but fibres for crafts and construction, and shade and ornamental elements are also obtained. However, its presence in the landscape is obviously diverse, highly localized even as a garden species.

Much more information can be found on mastic and terebinth trees (Pistacia lentiscus, P. terebinthus) under the name darw, mastic producing plants, which are also referred to by many agronomists (Ibn al-'Awwām, 1988; Ibn Bașșāl, 1995): the terebinth ("cornicabra", Pistacia terebinthus) was called 'green bean tree', while the 'small terebinth' seems to correspond to the mastic tree ("lentisco", Pistacia lentiscus), and a third species, the 'black mastic tree', may relate to the wild pistachio or Atlas mastic tree ("almácigo", Pistacia atlantica).

\section{Coniferous forests}

\section{Pine forests}

Pineforestsarementionedinvarioushistoric-geographical texts (Romero Funes, 2014), in places like the Serrania of Cuenca, mountains south of Tortosa (probably, 
Puertos de Beceite) in the Tagus river fonts, or on some Almería mountains. In the texts of Andalusi agronomists and botanists, pines appear under the term sanawbar, often referring to Pinus pinea but also to $P$. pinaster, P. sylvestris, $P$. halepensis and $P$. nigra on some other occasions. Ibn al-'Awwām (1988) refers to $P$. pinaster and quotes a maritime pine with "large heads". It is identified even better in Abū 1-Jayr (2004-2010), who writes about the size of the cone and the possibility of obtaining tar or pitch from the resin. It is said to be abundant in mountain ranges near Tortosa, where Scots pine (Pinus sylvestris) is also mentioned as the main source of timber for vessel masts, transported to the southern ports of alAndalus (Vallvé, 1986). The same author, Abū 1-Jayr, also mentions agrūy, a species with a stiff, consistent leaf, typical of northern areas and cold climates in alAndalus, with small cones resembling those of black pine ( $P$. nigra subsp. salzmannii). The diffuse reference to the most abundant and common pine species on the Andalusi coast and in low mountains, Aleppo pine (P. halepensis), is surprising. It was well known and widely used, despite the poor quality of its wood, for the extraction of resins and oils.

\section{Savin and Spanish junipers}

Mediterranean forests were also exploited for their junipers and savins. Abū 1-Jayr (2004-2010), in his botanical treatise under 'ar 'ar, describes various species of Juniperus, savin junipers being differentiated under the term abhal.

Carabaza et al. (2004), cited the possibility of identifying Tetraclinis articulata under the Arabic term 'ar'ar. Thanks to Abū 1-Jayr (2004-2010), this mention can be verified by what he considers to be one of the "varieties" of 'ar 'ar, including all the juniper species (Juniperus spp.) and, probably, T. articulata. Abellán Pérez (2004) agrees with this identification and locates the araar in some localities of the Iberian Peninsula and North Africa. Indeed, in the Algerian mountains of Tlemcen, forests of this cupressaceous tree are still preserved, as well as in Morocco and northern Tunisia. The mention of this species south of Arcos de la Frontera (Cádiz), in a place called Montifarti -or Montifarte-, makes us think of the foothills of Jerez and gives certainty to those who consider as being indigenous the population of century-old trees still preserved in Coto del Rey in Doñana National Park, Hinojos (Huelva; Baonza, 2010).

Abū 1-Jayr's morphological description in 'Umdat al-tabīb (2004-2010) triggers some doubts about it. However, Ibn Șālih, a Sevillian author (XII ${ }^{\text {th }}-X I^{t^{\text {th }}}$ c.) with experience in Africa, in an anonymous comment on Dioscorides's Materia Medica (1988), includes a highly accurate description of the tetravalve cone of $T$. articulata. Nevertheless, it can only be inferred that he knew the species well, as it has never been categorically affirmed that it grew in the Andalusi territory. As a result, we have to admit that the identification of this variety of 'ar'ar as T. articulata is still subject to some uncertainty.

\section{Yew tree forests}

There is no doubt about the identification of the yew tree (Taxus baccata), already a rare species in the southern half of Iberia during the Middle Ages. Nowadays, there are only a few hundred individuals confined in the Cazorla, Tejeda and Nevada mountain ranges. Of great interest is the mention of its presence in Tortosa, confirmed by the cosmographer al-Qazwīnī (Carabaza, 2004); this could explain the presence of one principal centre of Iberian relict yews in the mountains around Beceite (Teruel province). Geobotanically, even more relevant is the reference to the yew in the work of Abu 1-Jayr (2004-2010) in Constantina (Sierra Norte, Seville province) given the current absence of this species in a wild form throughout the south-western quadrant of the Peninsula. Historic-geographical texts also describe yews in Segura de la Sierra (Jaén), as recorded by Carabaza (2004).

The same botanical text (2004-2010) warns us of the poisonous nature of the whole plant, and mentions the main, most highly valued use of its timber, considered as being that most suitable for the construction of arrow bows since ancient times.

\section{Mixed and broadleaved forests}

As expected, the species of these forests are not among those most cited in the texts of Andalusi geoponists and botanists. However, in diverse localities of interest mentions of species like Pyrenean oaks (Quercus pyrenaica), maples (Acer spp.), whitebeam tree (Sorbus aria) and holly trees (Ilex aquifolium) with yews (Taxus baccata) can be found. For instance, chestnut groves (Castanea sativa) are mentioned in Tarragona, Toledo, Granada, Guadix and Salobreña (Carabaza, 2004).

Maples, Acer monspessulanum, A. granatense and A. pseudoplatanus have been identified, despite their confusing denomination in Andalusi agronomic and botanical texts, as this name is often used for more than one species (polysemy). As an example, the term qayqab refers to hackberry (Celtis australis) but Abū 1-Jayr (2004-2010) also refers to maples with smaller leaves (trilobed) A. campestre or A. opalus. Mentions of their abundance in the Granada mountain ranges would refer to the $A$. granatense, a taxon still frequent in these mountains. The term $d u l b$ generally corresponds to the 'Umda (2004-2010) entry for alder (Alnus glutinosa), but, under this term, other agronomists indicated "plane tree" (Platanus orientalis), and it also identifies $A$. pseudoplatanus, which is said to be a good bat repellent. The longevity of maples, and the quality and hardness of their wood are also recognized.

\section{Riparian forests}

\section{Poplar forests}

Poplars (Populus spp.) are mentioned on the banks of the Guadalquivir river, with precise references to their ecology (suitable trees for waterlogged terrains) and the 
use of their timber in carpentry, despite being softwood, has been pointed out. The same considerations extend to willows (Salix spp.) șașāf; mainly Salix alba in Ibn al-'Awwām (1988), and, more broadly, to other species according to Abū 1-Jayr (2004-2010), who also uses the name garab when writing about more shrub species, useful for basketry due their small coarse and knobbly branches, such as purple willow or wicker ( $S$. purpurea, S. viminalis) plants.

\section{EIm forests}

Elms are named with the term našam, also used for different riverbank deciduous trees such as poplars, willows and ash trees (Ibn al-'Awwām, 1988). The latter appear in Abū 1-Jayr (2004-2010) under the term hawr, with which elms are also recognized in al-Andalus and North Africa. Agronomists like Ibn Bașșāl (1995) and Ibn al-'Awwām (1988) discuss their riparian habitat, plantations near wells, in ditches and humid places, their limited edaphic requirements, and their planting techniques. In the always detailed botanical description of Abū l-Jayr they seem to correspond to Ulmus minor.

\section{Ash tree forests}

The name dardār has been applied to elm in almost all eastern countries except Syria, where it was used to designate ash (Maïmonide, 1940). This last name was also adopted in Egypt, the Maghreb and al-Andalus. We have identified dardār as Fraxinus angustifolia, although Abū 1-Jayr (2004-2010) also refers to other species of Fraxinus as "Galicians" and "franks", which may correspond to $F$. excelsior. No details are given about its medicinal uses, but it is said that its wood is dense, tenacious, elastic and solid. The ecological preferences mentioned are correct, as both species are said to grow near rivers and streams.

\section{Alders and hazel tree forests}

Identifying dulb as alder (Alnus glutinosa) is due to the precise diagnosis in Abū 1-Jayr's, the 'Umda (20042010): " it is that kind of large tree which has leaves like those of the mulberry tree, only smaller and more rounded, saw-toothed, smooth, between green and black in colour... the fruit is like a bean in size, or larger, it is elongated, cone-shaped, like a long green pepper, and its flowers are green, yellow and greyish... this grain is its nut and its timber is reddish in colour". With regard to its ecology, he is equally right in stating that "it grows along rivers, in humid mountains with abundant water". He is also right in warning about its poisonous nature, in spite of its many medicinal virtues. The tree bark contains tannins and flavonoid glycosides, so its branches and leaves are not recommended as fodder for livestock.

Regarding the hazel tree (Corylus avellana), once again, we find the expression: 'transplanted from the mountains to the orchards' of an enormous interpretative value for understanding the domestication and gen- eration processes of local varieties. Of great interest is the mention of its abundance as a wild tree, because of its ecological, historical and phytogeographical values.

\section{Thermophilic riparian forests}

Andalusi tamarisk forests are described under the word tarfā', which designates Iberian Tamarix species (corresponding mainly to Tamarix africana and $T$. canariensis) differentiated from atl (Tamarix aphylla) also mentioned in the manuscripts. Oleander (diflà) is widely recognized by al-Andalus authors and evidencing their broad knowledge of the plant; its toxicity, use as a poison, vermin repellent and its ornamental value. Along with oleander, Iberian bushweeds ("tamujo") are also cited. This will be dealt with monographically below.

\section{Shrubbery and bushes}

\section{Strawberry tree and heath groves}

Strawberry tree (Arbutus unedo) is a well-known species among those conforming forests but little has been said of it as a fruit crop. The Andalusi authors reveal a good knowledge of its ecological requirements: (acid soils); propagation and cultivation systems, including the slowness of seed germination; the extraction of young plants from the mountains, as a way to enhance orchards and gardens, which demonstrates the efforts made to domesticate and cultivate it as a crop. Its wood was also used in marquetry, cabinetmaking, turnery and for making arrows. One of its Arabic names, hinnā' a hmmar, red henna, is justified not only for the reddish colour of the heartwood, but also for its use as a leather dye, known since ancient times in countries of North Africa (Rivera \& Obón, 1991). However, mention is made of the damaging effects of its excessive consumption as a fruit. Heather (mainly Erica arborea) is very rarely mentioned in Antiquity and Middle Ages treatises, though Abū 1-Jayr clearly does so. Based on Dioscorides and the work of the geographer and botanist al-Bakrī (1968), both Abū 1-Jayr (2004-2010) and Ibn al-Bayțār (1987) write about the use of heather charcoal by blacksmiths, and the use of its flowers to cure vermin or snake bites but also indicate the poor quality of honey made from its flowers.

\section{Rockrose, rosemary and thyme fields}

Several species of rockrose shrubby formations ('jarales') can be identified in al-Andalus under different names, a fact that has given rise to confusion. The botanical work of Abū 1-Jayr (2004-2010) provides a testimony of some Cistaceae employed for laudanum extraction and, secondarily, the use of its timber as fuel and seeds for food (bread and soups) in times of famine. Rosemary, sages and flax-leaved daphne (Daphne gnidium) can be equally recognized although it is surprisingly difficult to find significant mentions of the use of rosemary and its cultivation, which made its identification a difficult task only possible with the help of Dioscorides (1983) and 
Abū 1-Jayr (2004-2010) in texts where rosemary appears

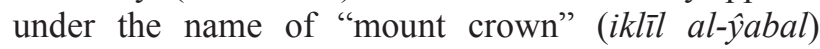
associated with thyme (șa 'âtir) and mugwort (šš hạt).

\section{Leguminous shrubs}

Thickets characterized by the dominance or abundance of brooms, Retama, Ulex, Genista and Citysus ('retamares'), appear under the term ratam (mainly Retama sphaerocarpa, 'white broom') in the Abū 1-Jayr (2004-2010) botanical text. This word has also been applied to other brooms such as Cytisus scoparius and some Genista species. The thorny leguminous species are known in Spanish under names like 'hiniestas' or 'aulagas', referring to Genista scorpius (due to the golden yellow colour of the flowers cited), G. hirsuta or Ulex baeticus. Otherwise such a remarkable text (the 'Umda), leaves us, however, discontented with weaver's broom (Spartium junceum), a species that could not be identified confidently in it but would have already been introduced at that time and used for textiles, perfumes, as a dye and an ornamental plant.

\section{Other thorny thickets (boxthorn, barberries, hawthorns bushes)}

Crataegus monogyna has been recognized, among other species described by Ibn al-'Awwām (1988), as being a "montesino" -from the mountains- a tree with bright red fruit, the size of a fat, sweet and pleasant to the palate chickpea, and two other grains, similar to those of the black nightshade". Under the term sufayra $\bar{a}$ ' a large group of thorny species, belonging to the Rhamnus, Lycium and Berberis genera, offers resistance to any precise identification. The word awsay seems to designate boxthorn (Lycium intricatum) and buckthorn (Rhamnus spp.). In Abū 1-Jayr (2004-2010) this term is assigned to several thorny shrubs with antiinflammatory properties, used in the treatment of skin diseases, yielding food fruits and used for fences, which leads us to think of Lycium intricatum or Zizyphus lotus. To be more specific, awsay ahmar must be buckthorn (Rhamnus alaternus), but there are always doubts about za 'rūr (Crataegus azarolus) if we consider the diagnosis of Abū l-Jayr's 'Umda. Boxwood (Buxus sempervirens), will be analysed later

\section{Singular tree and shrub species}

The formations investigated up to this point have permitted the recognition of over a hundred and twenty species, which, in view of their wide distribution or abundant presence in Iberian plant landscapes, do not signify any particular novelty in the ensemble of the species habitually identified in the translations and assessments of Andalusí botanical and agricultural treatises. However, in addition to them, and to the indisputable relevance of the fact that their citation was very often accompanied by toponyms, uses and properties of ethnobotanical interest, or by utilization and cultivation techniques, the study of the texts has enabled the identification of several dozens more taxa of a highly singular interest. Many of them were ignored up to then, so that they represent the first documented mention of Iberian flora.

We shall leave for another occasion the analysis and assessment of the first citations for the western Mediterranean of oriental woody species escaping cultivation and integrated into some landscapes (such as the case of Rhus coriaria or Elaeagnus angustifolia) and other questionably forest ones, but which are at least ornamental, like Melia acederach, Cercis siliquastrum, Moringa oleifera, Caesalpinia sapan, Ficus sycomorus, Cordia myxa o Acacia spp. However, there are others which do stand out as being unique elements of alAndalus flora, and we have paid special attention to them. These are:

\section{Anagyris foetida}

The foetid bean trefoil has been used since Antiquity both for its toxicity (poison) and as a popular medicine, recognizing its ability to produce vomiting along with other properties (anti-inflammatory, analgesic and antiasthmatic) due to the presence of two toxic principles: cytisine, common in other legumes, and anagyrine (more specific, to which its emetic properties are due). Uses and properties mentioned by the Andalusi authors followed the experience of Dioscorides, but also provided new applications in obstetrics. We agree with the opinion and observations of authors like Quer (1762-1764), Pau (in Font Quer, 1961), Font Quer (1961) and Ruiz de la Torre (2006) regarding its character as an archaeophyte in the environments of castles and historic fortresses. We have added our own observations (Hernández Bermejo, 1987) on the vicinity of Medina Azahara in Córdoba, a unique location on the right-hand margin of the Guadalquivir valley, where a large population of foetid trefoil remains, adjacent to the eastern boundary of this archaeological site.

\section{Arctostaphylos uva-ursi}

Although this species has been identified, in some instances, under the romance term bayunbuh, we consider this to be wrong as we would agree with Abū 1-Jayr (2004-2010) on the term gällaš insofar as it was believed that the first description of bearberry was that of Clusio in the sixteenth century, on the basis of Iberian material (L'Écluse, 2005). Surprisingly, the precise Abū 1-Jayr botanical description was written almost four centuries before, under the romance term already mentioned. There are many diagnosis characters offering certainty about that first historical description of this bearberry : its manner of growth (creeping all over the soil); the shape of its leaves; the similarities that the author establishes with respect to the strawberry tree (phylogenetically close); the shape and colour of its fruit; its habitat and ecology, and even the locations in which the author had seen the plant (Uclés, Medinaceli, Molina, etc.) 


\section{Buxus sempervirens}

The agronomists dedicate very little extension to the genus Buxus, represented in al-Andalus by only two species: the one with a wider distribution but more northern, Buxus sempervirens (in Arabic baqs), and the Baetic-Balearic endemism Buxus balearica, only present in the mountains round the coast of Malaga, Granada and Almería (Gador). Both have medicinal properties and interest as ornamentals, but the former is widely used in many crafts for its wood and has been used as a blond hair dye in cosmetics. Much more difficult to explain is the comment on the alleged effects of spikes or boxwood stakes grafted at the foot of the pomegranate tree.

The description in the 'Umda (Abū 1-Jayr, 20042010) is somewhat confusing: it mentions a northern distribution area, towards the northern limit of alAndalus, meaning the Iberian and pre-Pyrenean ranges, where Buxus sempervirens is much more abundant and frequent, and where there are still craftsmen who make household good parts, toys and other items made of boxwood. The historical-geographical sources mention boxwood forests in the mountains of Tortosa, from where the wood is exported to the rest of al-Andalus, for the manufacture of diverse tools (Carabaza, 2004). However, its medicinal virtues do not coincide with those currently known. For instance, it points to antidiarrhoeal but not antifebrifugal properties, where the buxina alkaloid is said to have similar effects to those of quinine.

Unfortunately, we find no evidence of the Andalusi agronomists or botanists knowing about or distinguishing the second species of boxwood present in Al-Andalus, Buxus balearica.

\section{Celtis australis}

Hackberry appears in the Andalusi texts under the Arabic term $m \bar{i} s$, although some problems arise with its identification because certain agronomists confuse it with several varieties of našam (elms) and with qayqab (maples). The translator of Ibn al-'Awwām, Banqueri also misidentified the species by making it coincide with nabq (Zizyphus lotus) and sidr (Zizyphus spina-christi, Z. paliurus) (Ibn al-'Awwām, 1988).

The agronomists are not concerned with giving morphological data of the species, but they do refer to its frequent use for the demarcation of properties. For example, Ibn Bașșāl (1995) talks about its thick bark and "its round black fruit, quite sweet, with a small stone inside", data endorsed by the botanical treatise of Abū 1-Jayr (2004-2010). In this latter text, acceptable diagnostic figures are found: "a tree of an enormous size, a smooth, grey bark, leaves similar to those of peach and chestnut trees [leaflets] although larger, wider and curved at the tip, round fruit, smooth and green, black when ripe -in autumn-, with a stone inside [drupa] which is edible". Also, on its ecology: "its habitat is constituted by highlands covered by trees, humid and mountainous places, as well as ravines, near areas where water flows".

\section{Corema album}

Of great interest is the identification of the "camarina" (white crowberry or Portuguese crowberry) in the 'Umdat al-tabīb of Abū 1-Jayr (2004-2010) under the name of 'inab al-di'b (adive grapes), not only because of the precise description of its morphology, habitat and localities visited, but because it is probably the first historical mention of this species. In that text the name is applied to "a species of heather, with leaves similar in shape and size to those of heather, dense ones, on hard, woody branches, many of them rising from a single stem, reaching the height of a seated person, with very small purple flowers, succeeded by grains the size of those of alkekenji (Physallis sp.), hard and transparent, whose interior is seen from the outside as being pearl-white which, when ripened, turn bright red and are edible at the end of the spring". The author adds that "it grows on the coasts, on the riverbanks and in sandy areas near the sea, abounding everywhere. I have seen this variety in Santa Maria del Algarve, and in the Wādī Numūš area". This last hydronym possibly corresponds to the Arroyo Madre de las Marismas of Doñana (Huelva province).

\section{Flueggea tinctorea}

We identified 'awsây șagīr, literally "small hawthorn" ( Iberian bushweeds, "tamujo" in Spanish) in the 'Umda of Abū 1-Jayr (2004-2010) as being the Iberian endemism Flueggea tinctorea (= Securinega tinctorea) which, due to its area being restricted to the Iberian SW quadrant, could not have been known by Dioscorides. The translators into Spanish of that botanical text were mistaken, as so many previous ones were, confusing it with some boxthorns and buckthorns (Rhamnus sp., Lycium sp., Osyris alba, Globularia alypum). However, the Andalusi agronomists knew the plant well because of its abundance in the streams, ravines and rivers of south-west Iberia, on acid substrates (Sierra Morena and Extremadura shales) and because of its traditional use for making brooms, the demarcation of properties and some diffuse medicinal and dyeing properties. It is not surprising that our agronomists associated this Phyllantaceae (previously Euphorbiaceae) with some species of Rhamnaceae: Linnaeus himself made this mistake 500 years later. But all the facts that the 'Umda mentions agree on this plant, the well-known tamujo: thorny, reddish, with greenish-yellow leaves and resembling myrtle, fruits that redden first and then go brown when ripe - and, above all, for being a freatophyte that forms, together with the oleanders, riparian communities in a large part of Sierra Morena.

\section{Ilex aquifolium}

The aforementioned holly tree has not been found in the Andalusi agronomic texts, which is somewhat logical given its rarity and scarcity in al-Andalus territories, but we think that it can be identified among the species cited by Abū 1-Jayr (2004-2010) 'Umda, when referring to different chewable and aromatic gums, extracted from 
the plants and usable as a source of birdlime or glue. Abū l-Jayr cites the mistletoe (Viscum spp.), the sapistan plant (sebestén, Cordia myxa), the prickly cistus or gum rockrose (Cistus ladanifer), the root of the sorrel thistle (Carlina acaulis) and asphodels (Asphodelus spp.). The same author writes about a " chewable gum tree", which he compares (probably due to its size and general physiognomy) to castor beans and carob trees, and describes how a substance is extracted from its thick, green bark, and after crushing, macerating and cooking it, a birdlime or gum is obtained, with which animals are hunted. The localities where the author has seen the species are very consistent and place us in the Cazorla and Segura Mountains, where today there are holly populations ("acebedas").

The confusion between Viscum and Ilex, plants that have nothing to do with each other in their appearance and taxonomic nature, is currently maintained since both are still known as "mistletoe" and are used both in the extraction of gum and in winter as ornamental plants..

\section{Laurus nobilis}

It is very significant -and coherent with the phytogeography of the species- that the Sevillian authors (Ibn al-'Awwām, 1988 and Abū l-Jayr, 1991) consider the laurel as a "montesina" species and transmit a sense of its proximity with the expression: "From being a a wild plant it arrives at the orchards". However, al-Tignarī (2006) the author from Granada refers to it as a foreign species in his territory. Among the uses mentioned by Ibn al-'Awwām can be emphasized, in addition to being a condiment, its veterinary and medicinal uses for digestive and pulmonary diseases, which seem to be healed by the ingestion or aspiration of laurel leaf oils. In this sense, also notable is the mention of the main unguent of the Middle Ages: that of laurel buds cooked with mint that, according to Font Quer (1961), was used for various purposes such as ear or kidney pains and antiparasitics.

\section{Rhododendron ponticum subsp baeticum}

It is a pleasant surprise to be able to identify, in the botanical text of Abū l-Jayr (2004-2010), among the plants called diflà (oleanders), a "variety" that the author calls "riverine" (Nerium oleander), together with two other varieties called "montesina". Between the latter, there is a smaller one, with flowers in clusters and fruit that we have interpreted as being capsular, much more localized and present in one of the classic loci of Iberian rhododendron ("ojaranzo" Rhododendron ponticum): the Sierra de Monchique (southern Portugal). It can be argued, in addition, that the association between oleanders and ojaranzos has been maintained throughout the centuries, with the oleander -Nerium oleanderreceiving the name of "rhododendron" in Greek and keeping for "ojaranzo" the name of "adelfeiro" in Portuguese. However, it seems evident that Abū 1-Jayr would only have known this species slightly, because he described the already withered flowers as being white much paler than their usual pink hue.

\section{Vitex agnus-castus}

The wild, abundant chasteberry appears on the banks of the al-Andalus rivers along with oleanders and other riparian species. Nowadays it is very often cultivated in gardens but it was probably exclusively used taking wild plants in Andalusi times. Among the agronomists, only Ibn al-'Awwām mentions it (1988). He talks about its veterinary and insecticidal applications, and the use of its seeds as food in times of hunger, something that Galen had mentioned many centuries before. The 'Umda of Abū 1-Jayr (2004-2010) helps us, once again, to identify the species both from its morphological characters and from its well-known anaphrodisiac properties, which do not seem to be of interest to the agronomist. In his work, data are found of its intraspecific variability, due to the presence of individuals with blue flowers and others of pinkish-white ones, something that Laguna (16th century) in his translation of Dioscorides, obviated (Dioscorides, 1983). The description of the 'Umda alludes to its arborescent-shrubby appearance, the tenacity of its branches and the sort of silvery colour of its pentalobulate- shaped leaves.

Regarding the well-known anaphrodisiac virtues of its fruit (its antiestrogenic action has been proven), the 'Umda makes reference to them, quoting Dioscorides and Galen. For that reason, it is no surprise that its more popular Arabic name, also extensible to the seed, is habb al-faqd (seed loss). The same can be said of its Latin epithet, agnus-castus, translatable as "chaste lamb", which the man who made a continuous use of the plant would become.

\section{Zizhyphus lotus}

If the works of the Andalusi agronomists are considered, the mention of this species is not ensured. It is defined with the help of Abū 1-Jayr's 'Umda (2004-2010), in which it is described as a "montesina" species of the jujube or 'unnāb: a plant with a round, thin-skinned fruit the size of a bean, with large and very astringent stones, which grows in the mountains and is very abundant in the whole country. The evidence of the use of this species as a living hedge has been preserved even in the Medina Azahara settlement up to now (Hernández Bermejo, 1987), which leads us to think that Ziziphus lotus must have been well known by Andalusi authors.

\section{Other species}

After many years of work, experience and publications, we cannot consider the identification and diagnosis of the species and forest formations of al-Andalus as having come to an end. We have no certainty, for example, and despite opinions to the contrary, on the mention of such important and unique species as Abies pinsapo. Nor is there any assurance of others of a more northern ecology and distribution and, therefore, more reasonably absent, like Fagus sylvatica or Betula spp., and there is not enough evidence either to confirm the cultivation of some North African or Asian species mentioned and known in 
the texts of the agronomists, as in the cases of Argania spinosa, Mimusops laurifolia or Cinnamomum spp.

\section{Conclusions}

We find ourselves facing a dynamic, reticulated landscape, in which conservation and tradition are compatible with various processes of innovation and changes in that landscape, due to the domestication and introduction of new species together with a "meticulous" occupation of the territory. The encyclopaedic experience of some Andalusi authors stands out, for instance, in the case of Ibn al-'Awwām. The mention - and in some cases, also the introduction by direct action - of new oriental species in farming, gardens and landscapes as we see in Ibn Bașșāl. Direct cultivation practices can also be appreciated in Ibn-Bașșāl or al-Ṭignarī and, above all, the excellent knowledge of Iberian, mainly Mediterranean, wild flora, in Abū 1-Jayr's botany text, a work whose identification and valuation can never be deemed to be concluded.
In addition to the uniqueness of the species cited, many of them mentioned and described for the first time in the Iberian territory, we should underline the identification of certain processes, elements of change and transformations in the forest landscapes as well as in woody and ornamental crops. Also noteworthy are the domestication processes, evidenced by affirmations and comments on transfers from the mountains to the crop fields, and on tentative cultivation and use experiences. We have demonstrated the importance of species such as holm oaks, pines and poplars in forest landscapes, and their exploitation for wood, fruits and seeds in the case of yews, pines, box trees, ash trees, hackberry trees, strawberry trees and junipers. Finally, we have mentioned, without this being a decisive component of this work, part of the traditional knowledge associated with woody and forest species; an ethnobotanical heritage that was enriched at that time by the synthesis of local knowledge, together with the reading of texts and lessons received through travel and trade with cultures, countries and territories located east or south of al-Andalus.

\section{References}

Abellán Pérez, J. 2004. Poblamiento y administración provincial en al-Andalus: la cora de Sidonia. Sarriá, Málaga. Abū 1-Jayr. 1991. Kitāb al-filāḥa. Tratado de agricultura. In: Carabaza Bravo, J.M. (Ed. \& trad.). ICMA, Madrid.

Abū l-Jayr. 2004-2010. Kitāb 'Umdat al-țabīb fì ma'rifat al-nabāt (Libro base del médico para el conocimiento de la botánica). Bustamante, J., Corriente, F. \& Tilmatine, M. (Eds. \& trads.). CSIC, Madrid.

Al-Bakrī. 1968. Ŷugrāfiyyat al-Andalus wa-Ūrubba min kitāb al-Masālik wa-l-mamālik. Al-Haŷȳī, 'A. (Ed.). Dār al-Iršād, Beirut.

Al-Ṭignarī. 2006. Kitāb Zuhrat al-bustān wa-nuzhat al-adhān (Esplendor del jardín y recreo de las mentes). GarcíaSánchez, E. (Ed.). CSIC, Madrid.

Baonza Díaz, J. 2010. Tetraclinis articulata (Vahl.) Mast., especie probablemente autóctona en Doñana. Ecología 23: $139-152$.

Carabaza Bravo, J.M., García Sánchez, E.,Hernández Bermejo, J.E. \& Jiménez Ramírez, A. 2001. Árboles y arbustos en los textos agrícolas andalusíes (II). In: Álvarez de Morales, C. (Ed.). Ciencias de la Naturaleza en al-Andalus VI. Pp. 157-222. CSIC-EEA, Granada.

Carabaza Bravo, J.M. 2004. Especies arbóreas. In: Roldán Castro, F. (Ed). Paisajes y Naturaleza en al-Andalus. Pp: 181-198. El Legado Andalusí, Granada.

Carabaza Bravo, J.M., García Sánchez, E., Hernández Bermejo, J.E. \& Jiménez, A. 2004. Árboles y arbustos en alAndalus. CSIC, Madrid.

Carabaza Bravo, J.M., García Sánchez, E., Hernández Bermejo, J.E. \& Martín-Consuegra Fernández, E. 2014. Palmeras en al-Andalus. In: García-Sánchez, E. (Ed.). Ciencias de la Naturaleza en al-Andalus IX. Pp. $255-283$. CSIC-EEA, Granada.

Dioscórides. 1983. Acerca de la Materia Medicinal y de los venenos mortíferos. (Ed. facs. de la ed. de Salamanca de 1566 por A. de Laguna). Ed. Arte y Bibliofilia, Madrid.

Dioscórides. 1988. Dioscurides Triumphans. Ein anonymer arabischer Komentar (Ende 12. Jahrh. n. Chr.) zur Materia Medica. Dietrich, A. (Ed. \& trad.). 2 vols. Vandenhoeck \& Ruprecht, Göttingen.

Font Quer, P. 1961. Plantas medicinales. El Dioscórides renovado. Omega, Barcelona.

García-Sánchez, E. 1997. Les traités de hisba andalous: un exemple de matière médicale et botanique populaires. Arabica 44: 76-93.

García Sánchez, E., Carabaza, J.M., Hernández Bermejo, J.E. \& Jiménez Ramírez, A. 1998. Árboles y arbustos en los textos agrícolas andalusíes (I). In: Álvarez de Morales, C. (Ed.). Ciencias de la Naturaleza en al-Andalus V. Pp. 269-307. CSIC-EEA, Granada.

García-Sánchez, E. 2001. Las plantas textiles y tintóreas en al-Andalus. In: Marín, M. (Ed.). Tejer y vestir: de la Antigüedad al Islam. Pp. 417-451. CSIC, Madrid. 
García-Sánchez, E., Hernández Bermejo, J.E., Carabaza, J.M., Jiménez Ramírez, A. \& Martín-Consuegra, E. 2008. Plantas hortenses en al-Andalus: Monocotiledóneas. In: García-Sánchez, E. \& Álvarez de Morales, C. (Eds.). Ciencias de la Naturaleza en al-Andalus VIII. Pp. 123-201. CSIC-EEA, Granada.

García-Sánchez, E. \& Hernández-Bermejo, J.E. 2007. Ornamental Plants in Agricultural and Botanical Treatises from Al-Andalus. In: Conan, M. (Ed.). Middle East Garden Traditions: Unity and Diversity. Pp. 75-94. Dumbarton Oaks-Harvard University, Washington.

García-Sánchez, E., Carabaza, J.M. \& Hernández-Bermejo, J.E. 2018 (en prensa). Flora Agrícola y Forestal de AlAndalus. Vol II: Árboles y arbustos. MAGRAMA, Madrid.

García-Sánchez, E. \& Ramón-Laca. L. 2001. Sebestén y zumaque, dos frutos importados de Oriente durante la Edad Media. Anu. Estud. Med. 31(2): 867-881.

Hernández-Bermejo. J.E. 1987. Aproximación al estudio de las especies botánicas originariamente existentes en los jardines de Madīnat al-Zahrā'. Cuadernos de Madīnat al-Zahrā' 1: 61-80.

Hernández-Bermejo. J.E. 1990. Dificultades en la identificación e interpretación de las especies vegetales citadas por los autores hispanoárabes. Aplicación a la obra de Ibn Bașșāl. In: García-Sánchez, E. (Ed.). Ciencias de la Naturaleza en al-Andalus I. Pp. 241-163. CSIC-EEA, Granada.

Hernández-Bermejo, J.E. 1991. Botanical Foundations for the Restoration of Spanish Arabic Gardens: Study of the Plant Species Used and their Introduction during the Andalusi Period. In: Tjon Sie Fat, L. \& Jong, E. de. (Eds.). The Authentic Garden. Pp. 153-164. E.J. Brill, Leiden.

Hernández-Bermejo, J.E. 1999. Flora autóctona y ornamental de Córdoba en la época califal. In: Berbel-Vecino, J. \& Porcel, O. (Eds.). Las ordenanzas de limpieza de Córdoba (1498) y su proyección. Pp. 71-76. Serv. Publ. Univ. Córdoba, Córdoba.

Hernández-Bermejo, J.E. \& García-Sánchez, E. 1998. Economic Botany and Ethnobotany in al-Andalus (Iberian Peninsula: Tenth-Fifteenth Centuries), an Unknow Heritage of Mankind. Econ. Bot. 52: 15-26.

Hernández-Bermejo, J.E. \& García-Sánchez, E. 2008. Gramíneas en al-Andalus. In: García-Sánchez, E. \& Álvarez de Morales, C. (Eds.). Ciencias de la Naturaleza en al-Andalus VIII. Pp. 235-287. CSIC-EEA, Granada.

Hernández-Bermejo, J.E. \& García-Sánchez, E. 2009. Tulips: an ornamental crop in the Andalusian Middle Ages. Econ. Bot. 63(1): 60-66.

Hernández-Bermejo, J.E., García-Sánchez, E., Carabaza, J.M., Martín-Consuegra, E. \& Jiménez, A. 2012. Flora Agrícola y Forestal de Al-Andalus. Vol I: Monocotiledóneas. MAGRAMA, Madrid.

Hernández-Bermejo, J.E. \& García-Sánchez. E. (Eds.). 2015. Huertas del Generalife: Paisajes agrícolas de alAndalus... en busca de la autenticidad. Patronato de la Alhambra y Generalife-Junta de Andalucía \& Ed. Comares, Granada.

Ibn al-‘Awwām. 1988. Kitāb al-Filāḥa. Libro de agricultura. Banqueri, J.A. (Ed. \& trad.). 2 vols. Hernández-Bermejo, J.E. \& García-Sánchez, E. (Estudio preliminar). Madrid: Ministerio de Agricultura. (Repr. facs. de la ed. de Madrid, 1802).

Ibn Bașșāl. 1995. Kitāb al-Qaṣd wa-l-bayān. Libro de agricultura. Millás Vallicrosa, J.M. \& 'Azīmān, M. (Eds. \& trads.). García-Sánchez, E. \& Hernández-Bermejo, J.E. (Estudio preliminar). Sierra Nevada 95, Granada. (Reprod. facs. de la ed. de Tetuán, 1955).

Ibn al-Bayțār. 1987. Traité des Simples. Leclerc, L. (Trad.). 3 vols. IMA, París. (Reproduc. facs. ed. de Imp. Nationale, París, 1877-1883).

L'Écluse, Ch. de. 2005. Descripción de algunas plantas raras encontradas en España y Portugal. (Amberes, 1576). Ramón-Laca Menéndez de Luarca, L. \& Morales Valverde, R. (Eds.). A. Domínguez García y F. Fernández González (Trads.). Junta de Castilla y León, Valladolid.

Maïmonide. 1940. Šarh asmā’ al-‘uqqār. Un glossaire de matière médicale composé par Maïmonide. Meyerhof, M. (Ed. \& trad.). Inst. Fr. Arch. Oriental, El Cairo.

Quer, J. 1762-1764. Flora española o historia de las plantas que se crían en España. Vols. I-IV. Ibarra, Madrid.

Rivera Nuñez, D. \& Obón de Castro, C. 1991. La Guía Incafo de las plantas útiles y venenosas de la Península Ibérica y Baleares (excluidas medicinales). Ed. Incafo, Madrid.

Romero Funes, C. 2014. Secular recorrido por tierras y paisajes andalusíes. In: García-Sánchez, E. (Ed.). Ciencias de la Naturaleza en al-Andalus IX. Pp. 231-254. CSIC-EEA, Granada.

Ruiz de la Torre, J. 2006. Flora Mayor. Min. Med. Amb., Madrid.

Sanz Elorza, M., González Bernardo, F., Serreta Oliván, A. \& Gavilán Iglesias, L.P. 2010. Invasiveness of alien vascular plants in six arid zones of Europe, Africa and America. Lazaroa 31: 109-126.

Vallvé, J. 1986. La división territorial de la España Musulmana. CSIC, Madrid. 